\title{
Alcanivorax dieselolei sp. nov., a novel alkane-degrading bacterium isolated from sea water and deep-sea sediment
}

\author{
Chenli Liu and Zongze Shao
}

Correspondence

Zongze Shao

shaozz@163.com
Key Laboratory of Marine Biogenetic Resources, Third Institute of Oceanography, State Oceanic Administration, People's Republic of China

Two bacterial strains, $B-5^{\top}$ and NO1A, were isolated from the surface water of the Bohai Sea and deep-sea sediment of the east Pacific Ocean, respectively. Both strains were halophilic, aerobic, Gram-negative, non-spore-forming, catalase- and oxidase-positive motile rods. They grew on a restricted spectrum of organic compounds, including some organic acids and alkanes. On the basis of $16 \mathrm{~S}$ rRNA gene sequence similarity, strains $\mathrm{B}-5^{\top}$ and NO1A were shown to belong to the $\gamma$-Proteobacteria. Highest similarity values were found with Alcanivorax venustensis (95.2\%), Alcanivorax jadensis (94.6\%) and Alcanivorax borkumensis (94.1\%). Principal fatty acids of both strains were $C_{16: 0}, C_{16: 1} \omega 7 c$ and $C_{18: 1} \omega 7 c$. The chemotaxonomically characteristic fatty acid $\mathrm{C}_{19: 0}$ cyclo $\omega 8 \mathrm{c}$ was also detected. On the basis of the above, together with results of physiological and biochemical tests, DNA-DNA hybridization, comparisons of 16S-23S internal transcribed spacer sequences and comparisons of the partial deduced amino acid sequence of alkane hydroxylase, both strains were affiliated to the genus Alcanivorax but were differentiated from recognized Alcanivorax species. Therefore, a novel species, Alcanivorax dieselolei sp. nov., represented by strains $B-5^{\top}$ and NO1A is proposed, with the type strain $\mathrm{B}-5^{\top}\left(=\mathrm{DSM} 16502^{\top}=\right.$ CGMCC $\left.1.3690^{\top}\right)$.
The genus Alcanivorax comprises three recognized species at present. The type species, Alcanivorax borkumensis, was first described in 1998 to accommodate Gram-negative, halophilic, aerobic $\gamma$-Proteobacteria that use aliphatic hydrocarbons as the sole source of carbon and energy (Yakimov et al., 1998). A second species, Alcanivorax venustensis, was subsequently described and the misclassified species [Fundibacter] jadensis was assigned to Alcanivorax jadensis (Fernández-Martínez et al., 2003). Since 1998, the isolation of Alcanivorax species, or detection of their $16 \mathrm{~S}$ rRNA gene

Abbreviations: AlkB (alkB), alkane hydroxylase; ITS, internally transcribed spacer.

The GenBank/EMBL/DDBJ accession numbers for the nucleotide sequences reported in this study are AY683537 (A. dieselolei $\mathrm{B}-5^{\top}$, 16S rRNA gene), AY683538 (B-5 $5^{\top}$, large ITS), AY683539 (B-5 ${ }^{\top}$, small ITS), AY683540 (B-5' ${ }^{\top}$, partial alkB gene), AY683531 (A. dieselolei N01A, 16S rRNA gene), AY683532 (NO1A, large ITS), AY683533 (N01A, small ITS), AY683534 (NO1A, partial alkB gene), AY683536 (A. jadensis T9' ${ }^{\top}$, partial alkB gene) and AY683535 (A. venustensis $\mathrm{ISO}^{\top}$, partial alkB gene).

Transmission electron micrographs of cells of strains $B-5^{\top}$ and NO1A and dendrograms showing the phylogenetic positions of the two strains plus recognized members of the genus Alcanivorax based on $16 \mathrm{~S}$ rRNA, ITS and alkB gene sequences are available as supplementary figures in IJSEM Online, together with a table giving DNA-DNA relatedness values. sequences, from diverse habitats worldwide has been reported increasingly. Thus they are regarded as cosmopolitan bacteria. This group of marine bacteria exclusively uses petroleum oil hydrocarbons as sources of carbon and energy, and has been used for bioremediative interventions in polluted marine and coastal systems. In addition, Alcanivorax species have obvious potential to produce biocatalysts in non-polluting industrial processes and to act as a biosensor for in situ monitoring of aromatic or aliphatic compounds (Golyshin et al., 2003).

Strain $B-5^{\mathrm{T}}$ was isolated from oil-contaminated surface water of the Bohai Sea at the Yellow River dock of Shengli oilfield in November 2001; this dock had suffered a long period of crude oil pollution. A second strain, designated NO1A, was retrieved from a deep-sea sediment sample in the east Pacific Ocean. This was collected by a multi-core sampler from Pacific nodule region A station $\left(7^{\circ} 13^{\prime} 46^{\prime \prime} \mathrm{N}\right.$, $153^{\circ} 52^{\prime} 19^{\prime \prime} \mathrm{W}, 5027 \mathrm{~m}$ water depth), a specific area with polymetallic nodules abundant on the sea bottom, during cruise DY105-11 of DAYANG Number 1 in 2001. The sediment samples were loaded into sterile Falcon tubes aboard ship and stored at $-20^{\circ} \mathrm{C}$ until use.

The artificial sea water medium (ASM) used for enrichment contained (per litre of distilled water) $10 \mathrm{~g}$ diesel fuel, $24 \mathrm{~g}$ $\mathrm{NaCl}, 7 \cdot 0 \mathrm{~g} \mathrm{MgSO}_{4} .7 \mathrm{H}_{2} \mathrm{O}, 1 \mathrm{~g} \mathrm{NH}_{4} \mathrm{NO}_{3}, 0 \cdot 7 \mathrm{~g} \mathrm{KCl}, 2 \cdot 0 \mathrm{~g}$ 
$\mathrm{KH}_{2} \mathrm{PO}_{4}, 3.0 \mathrm{~g} \mathrm{Na}_{2} \mathrm{HPO}_{4}$ and $10 \mathrm{ml}$ trace element solution, $\mathrm{pH} 7 \cdot 5$. Trace element solution contained (per litre of distilled water) $2 \mathrm{mg} \mathrm{CaCl}, 50 \mathrm{mg} \mathrm{FeCl}_{3} \cdot 6 \mathrm{H}_{2} \mathrm{O}, 0.5 \mathrm{mg}$ $\mathrm{CuSO}_{4}, 0.5 \mathrm{mg} \mathrm{MnCl}_{2} .4 \mathrm{H}_{2} \mathrm{O}$ and $10 \mathrm{mg} \mathrm{ZnSO}_{4} .7 \mathrm{H}_{2} \mathrm{O}$. Strains B- $5^{\mathrm{T}}$ and NO1A were cultivated on HLB and SM1 media. HLB was modified from Luria-Bertani (LB) medium (Sambrook et al., 1989), with the concentration of $\mathrm{NaCl}$ increased to $30 \mathrm{~g} \mathrm{l}^{-1}$. HLB was also used to check the presence of contaminants because both strains showed limited growth on this medium. SM1 (which was described by Yakimov et al., 1998) was used for routine cultivation of the isolates and most phenotypic tests, when supplemented with $10 \mathrm{~g} \mathrm{n}$-alkanes $\mathrm{l}^{-1}$ or $10 \mathrm{~g}$ sodium citrate $\mathrm{l}^{-1}$ as the sole carbon source. All cultures were incubated at $28^{\circ} \mathrm{C}$ and spun at 200 r.p.m. unless noted otherwise.

General cell morphology was studied under an Olympus inverted microscope using 3-day-old cultures of the strains grown on HLB agar. For electron microscopy, exponentialphase cells were harvested, subsequently suspended and absorbed on a Formvar-carbon-coated grid, then stained with phosphotungstic acid. Cells of both strains were Gramnegative, rod-shaped with lophotrichous flagella, and varied from 0.8 to $2.0 \mu \mathrm{m}$ in length and from 0.3 to $0.7 \mu \mathrm{m}$ in width (see Supplementary Fig. A in IJSEM Online). The optimal growth temperature was determined over the temperature range $4-55^{\circ} \mathrm{C}$. Sodium requirement was examined at $0,0 \cdot 5,1,5,7,10,15$ and $20 \%(\mathrm{w} / \mathrm{v}) \mathrm{NaCl}$. The following physiological and biochemical properties were examined according to standard methods: glucose fermentation, denitrification, catalase and oxidase activities, gelatin liquefaction and Tweenase, agarase, gelatinase, amylase and arginine dihydrolase activities. Results are given in the species description.

Tests for use of various organic substrates as sole carbon sources at a concentration of $0 \cdot 1 \%(\mathrm{w} / \mathrm{v})$ were performed in $5 \mathrm{ml} \mathrm{SM1}$ medium. The strains were characterized using Biolog GN plates as described by Ivanova et al. (1998). These results are also given in the species description. The chain length range of $n$-alkanes oxidized by strain $B-5^{\mathrm{T}}$ was determined according to the method of Smits et al. (2002) except that rhamnolipids and dioctylphthalate were not used. Experiments were repeated at least three times. Tests of surface tension were performed after 7 days incubation on SM1 medium supplemented with n-alkanes using a $\mathrm{Du}$ Noüy ring tension meter (McInerney et al., 1990). To test the ability of strain $\mathrm{B}-5^{\mathrm{T}}$ to produce surface-active glucolipids, total lipid was extracted and fractionated using the method described by Yakimov et al. (1998). Glucolipids were further separated by TLC and analysed using electrospray ionization mass spectrometry (ESI-MS) and tandem mass spectrometry (MSMS). Both strains were able to utilize various $\mathrm{n}$-alkanes as the sole carbon source, ranging in chain length at least from $\mathrm{C}_{5}$ to $\mathrm{C}_{36}$, which was wider than that of $A$. borkumensis $\left(\mathrm{C}_{6}\right.$ to $\mathrm{C}_{20}$; van Beilen et al., 2004). Plentiful growth was observed with $C_{8}$ to $C_{28}$ n-alkanes, while growth on $\mathrm{C}_{5}, \mathrm{C}_{6}$ and $\mathrm{C}_{7}$ n-alkanes was weak, probably because of the high volatility of these compounds, such that they are only poorly available to cells, or because of their toxicity as cell membrane lipid solvents. For the long-chain n-alkanes, without adding any surfactants, both strains could grow slowly on $\mathrm{C}_{32}$ and $\mathrm{C}_{36}$, although they were barely soluble in water. In addition, when strain $\mathrm{B}-5^{\mathrm{T}}$ utilized $\mathrm{C}_{24}$ as the sole carbon source, the surface tension of the culture was reduced from $71 \cdot 3$ to $42 \cdot 4 \mathrm{mN} \mathrm{m}^{-1}$ after 7 days cultivation. These results suggested that $\mathrm{B}-5^{\mathrm{T}}$ produced a biosurfactant. However, ESI-MS and MSMS failed to detect the presence of glucolipid-like compounds (data not shown), which were the typical products of $A$. borkumensis (Yakimov et al., 1998; Abraham et al., 1998).

Antibacterial activities were assessed as described by Kobayashi et al. (2003). Strain B- $5^{\mathrm{T}}$ was sensitive to neomycin, kanamycin, amikacin and polymyxin B, but resistant to fortum, cefuroxime, cephradin, cefazolin, cefalexin, piperacillin, carbenicillin, ampicillin, oxacillin, penicillin, erythromycin, minomycin, vibramycin, tetracycline, gentamicin, cefobid, rocephin, vancomycin, ofloxacin, midecamycin, ciprofloxacin, norfloxacin, furazolidone, clindamycin, chloromycetin and co-trimoxazole. By contrast, strain NO1A was only sensitive to polymyxin B within the above antibiotics.

Cellular fatty acid analysis was carried out at the identification service laboratories of the DSMZ (Deutsche Sammlung von Mikroorganismen und Zellkulturen, Braunschweig, Germany). The fatty acid profiles of both strains are shown in Table 1. The three major components, fatty acids $\mathrm{C}_{16: 0}$, $\mathrm{C}_{16: 1} \omega 7 c$ and $\mathrm{C}_{18: 1} \omega 7 c$, found in both strains and recognized Alcanivorax species were also the principal fatty acids in members of the genera Comamonas, Delftia (Tamaoka et al., 1987) and Hydrogenophaga (Willems et al., 1989) as well as in species of the genera Alicycliphilus (Mechichi et al., 2003) and Oceanisphaera (Romanenko et al., 2003). No conclusions could thus be drawn from the major fatty acid profiles. The minor fatty acid profiles of the two strains were more similar to A. venustensis $\mathrm{ISO}^{\mathrm{T}}$ than to $A$. borkumensis $\mathrm{SK} 2^{\mathrm{T}}$ or $A$. jadensis $\mathrm{T}^{\mathrm{T}}$. Fatty acid $\mathrm{C}_{19: 0}$ cyclo $\omega 8 c$, which was suggested as a characteristic chemotaxonomic marker of A. venustensis (Fernández-Martínez et al., 2003), was also detected in substantial amounts in strains $\mathrm{B}-5^{\mathrm{T}}$ and NO1A.

For genotypic characterization, DNA was prepared according to the method of Ausubel et al. (1995). The G+C content of the DNA was determined by HPLC after digestion of the DNA with nuclease P1 (Tamaoka \& Komagata, 1984; Mesbah \& Whitman, 1989). The 16S rRNA gene was amplified by PCR using the following primers: 16SF (positions 8-27 of the Escherichia coli numbering; 5'-AGAGTTTGATCCTGGCTCAG-3') and 16SR (positions 1512-1493, $5^{\prime}$-ACGGCTACCTTGTTACGACT-3'). The 16S-23S internally transcribed spacer (ITS) regions of strains $B-5^{\mathrm{T}}$ and NO1A were amplified with primers as described by García-Martínez et al. (1996, 1999). To amplify the partial fragment of the putative alkane hydroxylase gene $($ alkB), highly degenerate primers, MonF (positions 401-419, 
Table 1. Fatty acid compositions of strains $\mathrm{B}-5^{\mathrm{T}} / \mathrm{NO} 1 \mathrm{~A}, A$ borkumensis $\mathrm{SK}^{\top}, A$. venustensis $\mathrm{ISO}^{\top}$ and $A$. jadensis $\mathrm{Tg}^{\mathrm{T}}$

Strains: $1, \mathrm{~B}-5^{\mathrm{T}} / \mathrm{NO} 1 \mathrm{~A}$ (this study); 2, A. borkumensis $\mathrm{SK} 2^{\mathrm{T}}$ (Yakimov et al., 1998); 3, A. venustensis $\mathrm{ISO}^{\mathrm{T}}$ (Fernández-Martínez et al., 2003); 4, A. jadensis $\mathrm{T9}^{\mathrm{T}}$ (Bruns \& Berthe-Corti, 1999).

\begin{tabular}{|lcccc|}
\hline Fatty acid & $\mathbf{1}$ & $\mathbf{2}$ & $\mathbf{3}$ & $\mathbf{4}$ \\
\hline $\mathrm{C}_{10: 0}$ & $2 \cdot 55 / 3 \cdot 29$ & - & $3 \cdot 2$ & - \\
$\mathrm{C}_{10: 0} 3 \mathrm{OH}$ & $-/ 0 \cdot 16$ & - & - & - \\
$\mathrm{C}_{11: 0}$ & $0 \cdot 09 /-$ & - & - & - \\
$\mathrm{C}_{12: 0}$ & $8 \cdot 89 / 7 \cdot 9$ & - & $5 \cdot 1$ & $5 \cdot 2$ \\
$\mathrm{C}_{12: 0} 2 \mathrm{OH}$ & $0 \cdot 92 / 1 \cdot 12$ & - & - & $1 \cdot 1$ \\
$\mathrm{C}_{12: 0} 3 \mathrm{OH}$ & $2 \cdot 91 / 7 \cdot 18$ & - & $10 \cdot 7$ & $4 \cdot 9$ \\
$\mathrm{C}_{14: 0}$ & $0 \cdot 58 / 0 \cdot 51$ & $1 \cdot 1$ & $1 \cdot 4$ & $1 \cdot 7$ \\
$\mathrm{C}_{15: 1} \omega 6 c$ & $-/-$ & - & $1 \cdot 1$ & - \\
$\mathrm{C}_{15: 0}$ & $-/-$ & - & $2 \cdot 0$ & - \\
anteiso-C $15: 0$ & $-/-$ & - & - & $0 \cdot 2$ \\
$\mathrm{C}_{16: 1} \omega 7 c$ & $11 \cdot 32 \star / 11 \cdot 87 *$ & $17 \cdot 1 \dagger$ & $15 \cdot 4$ & $13 \cdot 5$ \\
$\mathrm{C}_{16: 0} \mathrm{~N}$ alcohol & $-/ 1 \cdot 25$ & - & - & - \\
$\mathrm{C}_{16: 0}$ & $32 \cdot 12 / 27 \cdot 0$ & $31 \cdot 5$ & $20 \cdot 2$ & $23 \cdot 4$ \\
$\mathrm{C}_{17: 1} \omega 8 c$ & $-/-$ & - & $0 \cdot 5$ & - \\
$\mathrm{C}_{17: 0}$ cyclo & $1 \cdot 11 / 0 \cdot 20$ & - & $1 \cdot 4$ & - \\
$\mathrm{C}_{17: 0}$ & $0 \cdot 25 / 0 \cdot 48$ & - & $2 \cdot 8$ & - \\
$\mathrm{C}_{18: 1} \omega 9 c$ & $-/-$ & - & $1 \cdot 2$ & - \\
$\mathrm{C}_{18: 1} \omega 7 c$ & $22 \cdot 41 / 31 \cdot 04$ & $47 \cdot 1 \ddagger$ & $19 \cdot 9$ & $20 \cdot 7$ \\
$\mathrm{C}_{18: 1} \omega 5 c$ & $-/-$ & $0 \cdot 2$ & - & - \\
$\mathrm{C}_{18: 0}$ & $0 \cdot 64 / 0 \cdot 89$ & $2 \cdot 0$ & $0 \cdot 9$ & - \\
anteiso-C & $-/-$ & - & $1 \cdot 2$ & - \\
$\mathrm{C}_{19: 0}$ cyclo $\omega 8 c \omega 7 c$ & $14 \cdot 27 / 5 \cdot 39$ & - & $10 \cdot 1$ & - \\
$\mathrm{Unknown}$ & $1 \cdot 92 / 1 \cdot 49$ & $0 \cdot 9$ & $1 \cdot 5$ & $29 \cdot 2$ \\
\hline
\end{tabular}

${ }^{\star}$ Sum of $\mathrm{C}_{16: 1} \omega 7 c / \mathrm{C}_{15: 0}$ iso $2 \mathrm{OH}$.

$\dagger$ Sum of $\mathrm{C}_{16: 1} \omega 7 c / \mathrm{C}_{16: 1} \omega 9$ t (Yakimov et al., 1998).

$\ddagger$ Sum of $\mathrm{C}_{18: 1} \omega 7 c / \mathrm{C}_{18: 1} \omega 7 t / \mathrm{C}_{18: 1} \omega 9 t / \mathrm{C}_{18: 1} \omega 12 c$ (Yakimov et al., 1998).

Pseudomonas putida GPol alkB numbering; 5'-TCAAYACMGSNCAYGARCT-3') and MonR (positions 820-801; $5^{\prime}$-CCGTARTGYTCNAYRTARTT-3'), were generated based on the conserved regions of several alkane hydroxylase gene sequences available in the GenBank database. The thermal cycles were taken in a T3 thermal cycler (Biometra). PCR products were purified and recovered by using a UNIQ-5 Column DNA Gel Extraction Kit (Sangon). Sequencing of the fragments was carried out on a model 377 automated DNA sequencer using a BigDye Terminators Cycle Sequencing Kit (Applied Biosystems). Sequence data were manually aligned with nucleotide sequences obtained from GenBank by using DNAMAN (version 5.1; Lynnon Biosoft). Alignments and phylogenetic analysis of ITS and alkB sequences were also carried out by using the DNAMAN program. Phylogenetic dendrograms of $16 \mathrm{~S}$ rRNA gene sequences were constructed by three different algorithms: the neighbour-joining method (Saitou \& Nei, 1987) using DNAMAN, and the maximum-likelihood (Felsenstein \& Churchill, 1996) and maximum-parsimony (Fitch, 1971) methods using the PHYLIP package (version 3.6a2.1; Felsenstein, 2004). Bootstrapping analysis was used to evaluate the tree topology of the data obtained from the three algorithms based on 1000 resamplings.

Nearly full-length 16S rRNA gene sequences (1504 nt) of strains $\mathrm{B}-5^{\mathrm{T}}$ and NO1A were determined. Sequence similarity between the two strains was $99.6 \%$. Their closest relatives were $A$. venustensis $\mathrm{ISO}^{\mathrm{T}}(95 \cdot 2 \%)$, A. jadensis $^{\mathrm{T} 9}{ }^{\mathrm{T}}$ $(94 \cdot 6 \%)$ and $A$. borkumensis SK2 ${ }^{\mathrm{T}}(94 \cdot 1 \%)$. In all the three phylogenetic trees, strains $\mathrm{B}-5^{\mathrm{T}}$ and NO1A were included in the Alcanivorax cluster, whose integrity was supported in $100 \%$ of the trees generated. The topology of the phylogenetic tree, shown in Fig. 1 (a more complete tree is available as Supplementary Fig. B in IJSEM Online), was reconstructed by using the neighbour-joining method. In Fig. 1, both strains branched with $A$. venustensis, but this branching point was only recovered in 570 trees out of 1000 generated in the bootstrap analysis. Similarly, the bootstrap value of this branch point was $52 \%$ for maximumparsimony analysis and $58 \%$ for maximum-likelihood analysis, which indicated that the branching pattern was not stable.

For ITS sequence comparison, PCR amplifications yielded two-band products in both strains. The lengths of the $16 \mathrm{~S}-23 \mathrm{~S}$ ITS sequences of strain $\mathrm{B}-5^{\mathrm{T}}$ were 612 and
0.05

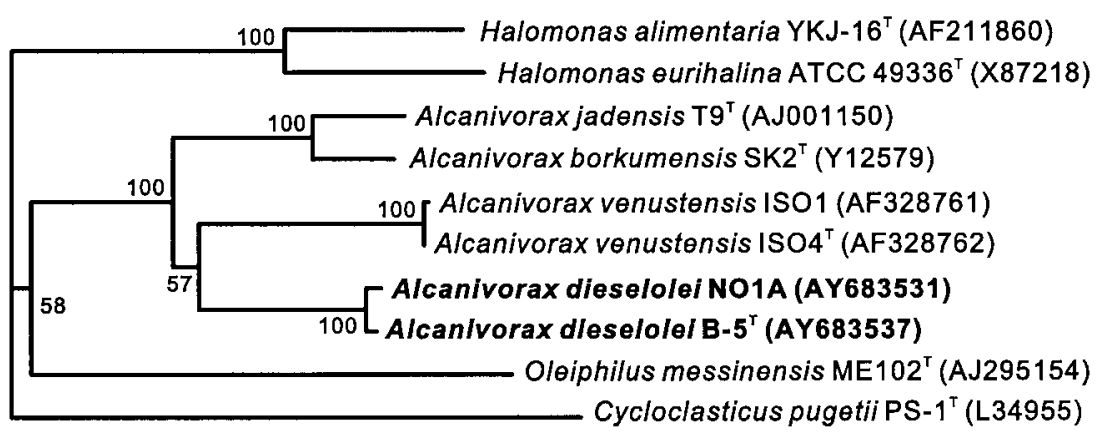

Fig. 1. Neighbour-joining tree showing the phylogenetic positions of strains $B-5^{\top}$ and NO1A and representatives of some other related taxa, based on 16S rRNA gene sequences. Bootstrap values (expressed as percentages of 1000 replications) are shown at branch points. Bar, 0.05 nucleotide substitution rate $\left(K_{\text {nuc }}\right)$ units. 
$322 \mathrm{nt}$, respectively. For strain NO1A, these were 585 and $322 \mathrm{nt}$, respectively. This indicated that strains $\mathrm{B}-5^{\mathrm{T}}$ and NO1A carried at least two rRNA operons. The large ITS of each strain contained two tRNA genes (Ile, Ala) that were absent in the small ITS. These features were in good agreement with those of other Alcanivorax species. Sequence analysis of the ITS confirmed the same groupings as that for the 16S rRNA gene (see Supplementary Fig. C in IJSEM Online). The ITS sequences of both strains and recognized Alcanivorax species had a mean variation of $23 \cdot 22 \pm 14 \cdot 79 \%$, which was still within the limit of a single and well-defined genus (García-Martínez \& RodríguezValera, 2000; Fernández-Martínez et al., 2003).

In the alkane hydroxylase (AlkB) sequence comparisons, a 420 nt DNA fragment was obtained from strain $\mathrm{B}-5^{\mathrm{T}}$ and encoded a polypeptide that showed 49.6 and $64.5 \%$ similarity to the corresponding internal region of the Pseudomonas putida GPo1 AlkB and Burkholderia cepacia RR10 AlkB sequence, respectively. The amplified fragment contained two histidine motifs and a fourth motif (NYXEHYG[L/M]) conserved among the alkane hydroxylases (Shanklin et al., 1994; Smits et al., 1999). Similarly, the partial putative alkB genes were amplified from strain NO1A, A. venustensis $\mathrm{ISO}^{\mathrm{T}}$ and $A$. jadensis $\mathrm{T}^{\mathrm{T}}$, but failed from $A$. borkumensis $\mathrm{SK} 2^{\mathrm{T}}$ (AlkB sequence data for $A$. borkumensis used in alignment were from van Beilen et al., 2004). Alignment of deduced partial AlkB sequences was generated on the basis of these $420 \mathrm{nt}$ internal gene fragments. The result showed that the AlkB sequences of strains $\mathrm{B}-5^{\mathrm{T}}$ and NO1A were nearly identical and closely related to that of $A$. venustensis $\mathrm{ISO} 4^{\mathrm{T}}$. The AlkB sequences of $A$. jadensis $\mathrm{T}^{\mathrm{T}}$ and $A$. borkumensis $\mathrm{SK} 2^{\mathrm{T}}$ formed a deep cluster and a separate group from the other taxa investigated (see Supplementary Fig. D in IJSEM Online). According to van Beilen et al. (2003), there was no clear linkage between the diversity of the alkB genes and phylogenetic lines. Nevertheless, when a particular genus, such as Mycobacterium or Burkholderia, was analysed independently, the phylogenetic tree of its partial AlkB was highly coincident with that of its $16 \mathrm{~S}$ rRNA gene sequence (data not shown), as was the case for Alcanivorax.

DNA-DNA relatedness was determined using genomic DNA from the two strains and type strains of all Alcanivorax species using the method described by Coram \& Rawlings (2002) and Tonjum et al. (1998). The genomic DNA of Escherichia coli $\mathrm{DH} 5 \alpha$ was used as an outgroup sample. Each membrane contained salmon sperm DNA (Sigma) as a negative control. Quantification of hybridization signals was carried out on a White/ultraviolet transilluminator (UVP) using Grab-IT 2.51 and GelBase/GelBlot-Pro 3.00 (Synoptics). The results are shown in Supplementary Table A in IJSEM Online. Each value was the mean of at least two hybridization experiments. Strains B- $5^{\mathrm{T}}$ and NO1A showed high DNA-DNA relatedness with each other (92\%), but were distinct from the type strains of Alcanivorax species based on low levels of DNA-DNA relatedness
(13-45\%). Notably, all strains had very low levels of DNA-DNA relatedness with E. coli DH5 $\alpha$ ( $\leqslant 7 \%)$. DNADNA relatedness among $A$. borkumensis $\mathrm{SK} 2^{\mathrm{T}}, A$. jadensis $\mathrm{T}^{\mathrm{T}}$ and $A$. venustensis $\mathrm{ISO}^{\mathrm{T}}$ fell in the range $17-49 \%$. A comparatively high level of DNA-DNA relatedness (36-45\%) was found between A. venustensis $\mathrm{ISO}^{\mathrm{T}}$ and the two novel strains.

According to the present results, strains $\mathrm{B}-5^{\mathrm{T}}$ and NO1A shared high similarities in phenotypic and genotypic characteristics, such as $99.6 \% 16 \mathrm{~S}$ rRNA gene sequence similarity and $92 \%$ DNA-DNA relatedness. Although isolated from two completely different marine habitats, the two strains should be classified as representing a single species. Phylogenetic analysis based on $16 \mathrm{~S}$ rRNA gene sequence comparison showed that strains $\mathrm{B}-5^{\mathrm{T}}$ and NO1A represented a novel species of the $\gamma$-Proteobacteria, branching within the clade of Alcanivorax and forming a distinct branch with $A$. venustensis. We initially considered that the two strains and $A$. venustensis should be classified in a new genus based on their close relationship in $16 \mathrm{~S}$ rRNA, ITS and $a l k B$ gene sequence data and fatty acid composition. However, this hypothesis was precluded for the following reasons. Firstly, there were no distinct and decisive traits to differentiate them from other members of the genus Alcanivorax. Secondly, the two strains and recognized species of the genus Alcanivorax shared comparatively high DNA-DNA relatedness values (13-45\%). Thirdly, the branching point of the cluster consisting of strains $\mathrm{B}-5^{\mathrm{T}}$ and NO1A and $A$. venustensis was statistically insignificant. Lastly, insufficient data regarding the fatty acids profiles of A. borkumensis and A. jadensis, as discussed by FernándezMartínez et al. (2003), made it difficult to draw any definitive conclusions.

Thus, according to their phylogenetic relationships, DNADNA hybridization, ITS and alkB gene sequence comparisons and phenotypic traits, strains $\mathrm{B}-5^{\mathrm{T}}$ and NO1A exhibited characteristics that defined the genus Alcanivorax. In addition, both strains have a number of distinct phenotypic features that allow them to be distinguished from other Alcanivorax species (Table 2), such as the ability to grow at $45^{\circ} \mathrm{C}$ and to utilize citrate, succinate and longchain n-alkanes. Therefore, we consider that the species represented by strains $\mathrm{B}-5^{\mathrm{T}}$ and NO1A belongs to a novel species of the genus Alcanivorax, for which the name Alcanivorax dieselolei sp. nov. is proposed.

\section{Description of Alcanivorax dieselolei sp. nov.}

Alcanivorax dieselolei (die.sel.o'le.i. N.L. masc. n. dieselius latinized family name of Rudolf Diesel; L. gen. neut. n. olei of oil; N.L. gen. neut. n. dieselolei of diesel oil, the sole carbon source used in the isolation procedure of the two strains).

Cells are $0 \cdot 8-2 \cdot 0 \mu \mathrm{m}$ long and $0 \cdot 3-0 \cdot 7 \mu \mathrm{m}$ wide, motile, lophotrichous, non-spore-forming, Gram-negative rods. Colonies on HLB agar are characteristically small, translucent, non-pigmented and slightly raised in the centre, with 
Table 2. Characteristics that differentiate $A$. dieselolei sp. nov. from other members of the genus Alcanivorax

Taxa: 1, A. dieselolei (this study); 2, A. borkumensis (Yakimov et al., 1998); 3, A. venustensis ISO4 ${ }^{\mathrm{T}}$ (Fernández-Martínez et al., 2003); 4, A. jadensis (Bruns \& Berthe-Corti, 1999). Data for utilization of organic acids for A. dieselolei were obtained from tests in SM1 medium. ND, No data; + , positive reaction or growth; -, no reaction or growth.

\begin{tabular}{|c|c|c|c|c|}
\hline Characteristic & 1 & 2 & 3 & 4 \\
\hline Motility, flagella arrangement &,+ Lophotrichous & - & + , Polar & - \\
\hline Ionic requirements & $\mathrm{Na}^{+}$ & Complex $\left(\mathrm{Na}^{+}, \mathrm{Mg}^{2+}\right)$ & Complex & $\mathrm{Na}^{+}$ \\
\hline \multicolumn{5}{|l|}{ Utilization of organic acids: } \\
\hline Citrate & + & - & - & - \\
\hline$\beta$-Oxoglutarate & - & + & - & ND \\
\hline$\gamma$-Hydroxybutyrate & + & - & + & ND \\
\hline Optimal temperature $\left({ }^{\circ} \mathrm{C}\right)$ & $28-35$ & $25-30$ & $23-25$ & 30 \\
\hline Growth at $4^{\circ} \mathrm{C}$ & - & - & + & - \\
\hline Growth at $45^{\circ} \mathrm{C}$ & + & - & - & - \\
\hline
\end{tabular}

irregular, transparent and halo-like peripheries. Mesophilic. Growth temperature ranges from 15 to $45^{\circ} \mathrm{C}$ (optimum $\left.28{ }^{\circ} \mathrm{C}\right) . \mathrm{NaCl}$ is required for growth; cells grow in $1-15 \%$ $\mathrm{NaCl}$ (optimum 3-7.5\%). Actively degrades Tween 80; catalase- and oxidase-positive, but negative for agarase, arginine dihydrolase, amylase and gelatinase. Nitrate is reduced to nitrite. Among the 95 carbon sources in the Biolog system, positive for Tweens 40 and 80, methyl pyruvate, mono-methyl succinate, acetic acid, citric acid, $\beta$ hydroxybutyric acid, $\gamma$-hydroxybutyric acid, $p$-hydroxy phenyl acetic acid, DL-lactic acid, propionic acid, bromo succinic acid and 2,3-butanediol. Negative for all carbohydrates using Biolog GN. Good growth occurs in SM1 medium with citrate, $p$-hydroxyphenylacetate, pyruvate, lactate or n-alkane as carbon source. Sensitive to neomycin, kanamycin, amikacin and polymyxin B. Cells are able to degrade n-alkanes with chain length $\mathrm{C}_{5}$ to $\mathrm{C}_{36}$. Cellular fatty acids are $\mathrm{C}_{16: 0}, \mathrm{C}_{18: 1} \omega 7 c, \mathrm{C}_{16: 1} \omega 7 c, \mathrm{C}_{19: 0}$ cyclo $\omega 8 c$, $\mathrm{C}_{12: 0}$ and $\mathrm{C}_{12: 0} 3 \mathrm{OH}$. $\mathrm{G}+\mathrm{C}$ content of the DNA is $62 \cdot 1-62 \cdot 5 \mathrm{~mol} \%$. Table 2 shows characteristics used to distinguish strain $\mathrm{B}-5^{\mathrm{T}}$ from other members of the genus Alcanivorax.

The type strain, B-5 $5^{\mathrm{T}}\left(=\mathrm{DSM} 16502^{\mathrm{T}}=\mathrm{CGMCC} 1.3690^{\mathrm{T}}\right)$, was isolated from an oil-contaminated sea water at the Yellow River dock of Shengli oilfield, Bohai Sea. Strain NO1A was isolated from a deep-sea sediment sample in the Pacific nodule region A station (5027 m water depth).

\section{Acknowledgements}

The type strains of A. borkumensis and A. jadensis were generous gifts from Dr Peter N. Golyshin and Dr Alke Bruns. We thank Dr R. Rosselló-Mora for his helpful discussions and critical review and Professor Dr Hans G. Trüper for his help with the etymology. This work was financially supported by 973 preliminary program (no. 202CCA05000), COMRA program (no. DY105-04-02-06) and SOA programs (nos A02302, HK03302).

\section{References}

Abraham, W. R., Meyer, H. \& Yakimov, M. (1998). Novel glycine containing glucolipids from the alkane using bacterium Alcanivorax borkumensis. Biochim Biophys Acta 1393, 57-62.

Ausubel, F. M., Brent, R., Kingston, R. E., Moore, D. D., Seidman, J. G., Smith, J. A. \& Struhl, K. (editors) (1995). Short Protocols in Molecular Biology: a Compendium of Methods from Current Protocols in Molecular Biology, 3rd edn. New York: Wiley.

Bruns, A. \& Berthe-Corti, L. (1999). Fundibacter jadensis gen. nov., sp. nov., a new slightly halophilic bacterium, isolated from intertidal sediment. Int J Syst Bacteriol 49, 441-448.

Coram, N. J. \& Rawlings, D. E. (2002). Molecular relationship between two groups of the genus Leptospirillum and the finding that Leptospirillum ferriphilum sp. nov. dominates South African commercial biooxidation tanks that operate at $40{ }^{\circ} \mathrm{C}$. Appl Environ Microbiol 68, 838-845.

Felsenstein, J. (2004). PHYLIP (phylogeny inference package), version 3.6. Distributed by the author. Department of Genetics, University of Washington, Seattle, USA.

Felsenstein, J. \& Churchill, G. A. (1996). A Hidden Markov Model approach to variation among sites in rate of evolution. Mol Biol Evol 13, 93-104.

Fernández-Martínez, J., Pujalte, M. J., García-Martínez, J., Mata, M., Garay, E. \& Rodriguez-Valera, F. (2003). Description of Alcanivorax venustensis sp. nov. and reclassification of Fundibacter jadensis DSM $12178^{\mathrm{T}}$ (Bruns and Berthe-Corti 1999) as Alcanivorax jadensis comb. nov., members of the emended genus Alcanivorax. Int J Syst Evol Microbiol 53, 331-338.

Fitch, W. M. (1971). Toward defining the course of evolution: minimum change for a specified tree topology. Syst Zool 20, $406-416$. 
García-Martínez, J. \& Rodríguez-Valera, F. (2000). Microdiversity of uncultured marine prokaryotes: the SAR11 cluster and the marine Archaea of Group I. Mol Ecol 9, 935-948.

García-Martínez, J., Martínez-Murcia, A. J., Rodríguez-Valera, F. \& Zorraquino, A. (1996). Molecular evidence supporting the existence of two major groups in uropathogenic Escherichia coli. FEMS Immunol Med Microbiol 14, 231-244.

García-Martínez, J., Acinas, S. G., Anton, A. I. \& Rodríguez-Valera, F. (1999). Use of the $16 \mathrm{~S}-23 \mathrm{~S}$ ribosomal genes spacer region in studies of prokaryotic diversity. J Microbiol Methods 36, 55-64.

Golyshin, P. N., Martins Dos Santos, V. A., Kaiser, O. \& 8 other authors (2003). Genome sequence completed of Alcanivorax borkumensis, a hydrocarbon-degrading bacterium that plays a global role in oil removal from marine systems. J Biotechnol 106, 215-220.

Ivanova, E. P., Kiprianova, E. A., Mikhailov, V. V. \& 8 other authors (1998). Phenotypic diversity of Pseudoalteromonas citrea from different marine habitats and emendation of the description. Int J Syst Bacteriol 48, 247-256.

Kobayashi, T., Imada, C., Hiraishi, A., Tsujibo, H., Miyamoto, K., Inamori, Y., Hamada, N. \& Watanabe, E. (2003). Pseudoalteromonas sagamiensis sp. nov., a marine bacterium that produces protease inhibitors. Int J Syst Evol Microbiol 53, 1807-1811.

Mclnerney, M. J., Javaheri, M. \& Nagle, D. N., Jr (1990). Properties of the biosurfactant produced by Bacillus licheniformis strain JF-2.J Ind Microbiol 5, 95-102.

Mechichi, T., Stackebrandt, E. \& Fuchs, G. (2003). Alicycliphilus denitrificans gen. nov., sp. nov., a cyclohexanol-degrading, nitratereducing $\beta$-proteobacterium. Int J Syst Evol Microbiol 53, 147-152.

Mesbah, M. \& Whitman, W. B. (1989). Measurement of deoxyguanosine/thymidine ratios in complex mixtures by high-performance liquid chromatography for determination of the mole percentage guanine + cytosine of DNA. J Chromatogr 479, 297-306.

Romanenko, L. A., Schumann, P., Zhukova, N. V., Rohde, M., Mikhailov, V. V. \& Stackebrandt, E. (2003). Oceanisphaera litoralis gen. nov., sp. nov., a novel halophilic bacterium from marine bottom sediments. Int J Syst Evol Microbiol 53, 1885-1888.

Saitou, N. \& Nei, M. (1987). The neighbor-joining method: a new method for reconstructing phylogenetic trees. Mol Biol Evol 4, 406-425.

Sambrook, J., Fritsch, E. F. \& Maniatis, T. (1989). Molecular Cloning: a Laboratory Manual, 2nd edn. Cold Spring Harbor, NY: Cold Spring Harbor Laboratory.
Shanklin, J., Whittle, E. \& Fox, B. G. (1994). Eight histidine residues are catalytically essential in a membrane-associated iron enzyme, stearoyl-CoA desaturase, and are conserved in alkane hydroxylase and xylene monooxygenase. Biochemistry 33, 12787-12794.

Smits, T. H. M., Röthlisberger, M., Witholt, B. \& van Beilen, J. B. (1999). Molecular screening for alkane hydroxylase genes in Gramnegative and Gram-positive strains. Environ Microbiol 1, 307-317.

Smits, T. H. M., Balada, S. B., Witholt, B. \& van Beilen, J. B. (2002). Functional analysis of alkane hydroxylases from gram-negative and gram-positive bacteria. J Bacteriol 184, 1733-1742.

Tamaoka, J. \& Komagata, K. (1984). Determination of DNA base composition by reversed-phase high-performance liquid chromatography. FEMS Microbiol Lett 25, 125-128.

Tamaoka, J., Ha, D.-M. \& Komagata, K. (1987). Reclassification of Pseudomonas acidovorans den Dooren de Jong 1926 and Pseudomonas testosteroni Marcus and Talalay 1956 as Comamonas acidovorans comb. nov. and Comamonas testosteroni comb. nov., with an emended description of the genus Comamonas. Int J Syst Bacteriol 37, 52-59.

Tonjum, T., Welty, D. B., Jantzen, E. \& Small, P. L. (1998). Differentiation of Mycobacterium ulcerans, M. marinum, and $M$. haemophilum: mapping of their relationships to M. tuberculosis by fatty acid profile analysis, DNA-DNA hybridization, and 16S rRNA gene sequence analysis. J Clin Microbiol 36, 918-925.

van Beilen, J. B., Li, Z., Duetz, W. A., Smits, T. H. M. \& Witholt, B. (2003). Diversity of alkane hydroxylase systems in the environment. Oil Gas Sci Technol Rev 58, 427-440.

van Beilen, J. B., Marin, M. M., Smits, T. H., Rothlisberger, M., Franchini, A. G., Witholt, B. \& Rojo, F. (2004). Characterization of two alkane hydroxylase genes from the marine hydrocarbonoclastic bacterium Alcanivorax borkumensis. Environ Microbiol 6, 264-273.

Willems, A., Busse, J., Goor, M. \& 8 other authors (1989). Hydrogenophaga, a new genus of hydrogen-oxidizing bacteria that includes Hydrogenophaga flava comb. nov. (formerly Pseudomonas flava), Hydrogenophaga palleronii (formerly Pseudomonas palleronii), Hydrogenophaga pseudoflava (formerly Pseudomonas pseudoflava and "Pseudomonas carboxydoflava"), and Hydrogenophaga taeniospiralis (formerly Pseudomonas taeniospiralis). Int J Syst Bacteriol 39, 319-333.

Yakimov, M. M., Golyshin, P. N., Lang, S., Moore, E. R. B., Abraham, W. R., Lünsdorf, H. \& Timmis, K. N. (1998). Alcanivorax borkumensis gen. nov., sp. nov., a new, hydrocarbon-degrading and surfactant producing marine bacterium. Int J Syst Bacteriol 48, 339-348. 